\title{
Hydroxyapatite Lanthanum Oxide Composites
}

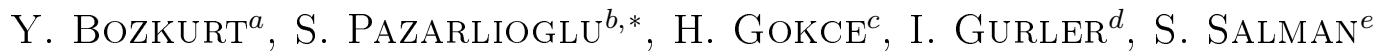 \\ ${ }^{a}$ Marmara University, Technology Faculty, Metallurgy and Materials \\ Engineering Department, 34722 Istanbul, Turkey \\ ${ }^{b}$ Marmara University, Technical Education Faculty, Metal Education \\ Deparment, Goztepe Campus, 34722, Istanbul/ Turkey \\ ${ }^{c}$ Istanbul Technical University, Prof. Dr. Adnan Tekin Material Science \\ \& Production Technologies Applied Research Center, 34469 Istanbul/ Turkey \\ ${ }^{d}$ Marmara University, Institute of Pure and Applied Sciences, Metal Education \\ Deparment, 34722 Istanbul/ Turkey \\ ${ }^{e}$ Mehmet Akif Ersoy University, Faculty of Engineering \& Architecture, Mechanical \\ Engineering Department, Istiklal Campus, 15100, Burdur/Turkey
}

\begin{abstract}
In the present study a commercially synthetic hydroxyapatite powders (CSHAp) were doped with lanthanum oxide ( 5 and 10 wt. $\% \mathrm{La}_{2} \mathrm{O}_{3}$ ). The composite powders were well homogenized and pelleted in an uniaxial mould at $350 \mathrm{MPa}$. Pelleted green bodies were sintered at five different temperatures. Finally, the effect of $\mathrm{La}_{2} \mathrm{O}_{3}$ amount on the microstructural and mechanical properties of CSHA was investigated. Microstructural properties were detected by X-ray diffraction patterns (XRD) and scanning electron microscope (SEM). Mechanical properties of the sintered samples were determined by the density, hardness and compression strength measurements. Experimental results show that the mechanical properties of $\mathrm{HA}$ can be improved by the doping of $\mathrm{La}_{2} \mathrm{O}_{3}$
\end{abstract}

DOI: $10.12693 /$ APhysPolA.127.1407

PACS: 87.85.jf

\section{Introduction}

The number of treated skeletal deficiencies steadily increases in a global scale due to accident/injury and/or bone defects. Although autogenous bone is most preferred for the treatment of bone defects, there are disadvantages and risks involved in using autogeneic bone such as post-operation pain, increased blood loss, secondary surgical wounds and risk of thrombosis. Allograft bone could overcome the above limitations, but it bears the risk of transmission of infection (e.g. HIV, Hepatitis, etc.). Another possible alternative is the use of effective and inexpensive biomaterials such as HA produces from different sources such as biologically derived and synthetic hydroxyapatite [1-3]. Despite of its desirable properties, the low fracture strength and poor fatigue resistance due to the instability of $\mathrm{OH}$ groups limit the use of its biomedical applications to non-load bearing applications. Low mechanical properties of HA can be improved by precise control of the microstructure and the use of various reinforcements [4-6]. One of the most commonly used methods to improve the mechanical properties of $\mathrm{HA}$, reinforcements of its with oxide based ceramics such as $\mathrm{ZrO}_{2}$ [7], $\mathrm{TiO}_{2}$ [8], $\mathrm{Al}_{2} \mathrm{O}_{3}$ [9], $\mathrm{MgO}$ [10], $\mathrm{BaTiO}_{3}$ [11] etc. In the present study, we doped a commercially synthetic hydroxyapatite powder with lanthanum oxide and the effect of lanthanum oxide on the microstructural and mechanical properties of CSHA was investigated.

\footnotetext{
* corresponding author; e-mail: spazarlioglu@marmara.edu.tr
}

\section{Materials and method}

\subsection{Materials}

A commercial HA powder $(5 \mu \mathrm{m}$, CAS Number: $1306-$ 06-5, Across Organics/Belqium) was used as matrix material and doped with lanthanum oxide $\left(5 \mu \mathrm{m}, \mathrm{La}_{2} \mathrm{O}_{3}, 5\right.$ and 10 wt.\%, CAS Number: 1312-81-8, Sigma Aldrich, Germany). The powders were firstly well homogenized in Restch PM 100 ball milling device in a zirconia coated stainless steel container with 15 zirconia balls and enough ethyl alcohol at $180 \mathrm{rpm}$ for $2 \mathrm{~h}$. Afterwards, they were pelleted at $350 \mathrm{MPa}$ according to a British Standard for compression tests [12]. Finally, the compacted green samples were sintered at 900, 1000, 1100, 1200 and $1300{ }^{\circ} \mathrm{C}$ for $4 \mathrm{~h}$ with the heating and the cooling rates of $5{ }^{\circ} \mathrm{C} / \mathrm{min}$.

\subsection{Mechanical properties}

Density of the sintered samples was calculated using Archimedes method. Relative densities of the sintered samples were calculated by comparing the measured densities with the theoretical densities of samples. (HA: $3.156 \mathrm{~g} / \mathrm{cm}^{3}, \mathrm{HA}-2.5 \mathrm{La}_{2} \mathrm{O}_{3}: 3.197 \mathrm{~g} / \mathrm{cm}^{3}, \mathrm{HA}-5 \mathrm{La}_{2} \mathrm{O}_{3}$ : $3.239 \mathrm{~g} / \mathrm{cm}^{3}$ and HA-10La $\mathrm{O}_{3}: 3.327 \mathrm{~g} / \mathrm{cm}^{3}$ ) The compression strengths of the samples were measured using Devotrans Universal testing device at $2 \mathrm{~mm} / \mathrm{min}$ speeds. Micro-vickers indentation method was used to determine the hardness of the sintered samples under the loads of $1.962 \mathrm{~N}$ for $20 \mathrm{~s}$. 


\subsection{Microstructural properties}

XRD patterns were obtained at room temperature in an X'Pert MPD Philips diffractometer using $\mathrm{Cu}-\mathrm{K} \alpha$ radiation in the range of $2 \theta\left(10-90^{\circ}\right)$. The microstructures of the samples were determined by scanning electron microscope (SEM, JOEL Ltd., JSM-5910 LV) after gold coating.

\section{Results and discussion}

The XRD patterns of CSHA and CSHA-La $\mathrm{O}_{3}$ composites are shown in Fig. 1. All peaks are compatible with HA (JCPDS file no.: 98-006-0428) and no other phases were detected for CSHA samples sintered between $900{ }^{\circ} \mathrm{C}$ and $1100{ }^{\circ} \mathrm{C}$. But, the samples sintered at higher temperatures betatricalcium phosphate $\left(\beta\right.$-TCP, at $\left.1200{ }^{\circ} \mathrm{C}\right)$ and beta/alphaTCP and also calcium oxide ( $\beta$-TCP, $\alpha$ $\mathrm{TCP}$ and $\mathrm{CaO}$, at $1300{ }^{\circ} \mathrm{C}$ ) phases were determined in addition to HA as shown in Fig. 1a. For all CSHA$\mathrm{La}_{2} \mathrm{O}_{3}$ composites were detected $\mathrm{HA}$, lanthanum hydroxide $\left(\mathrm{La}(\mathrm{OH})_{3}\right)$ and $\mathrm{La}_{2} \mathrm{O}_{3}$ phases sintered at $900{ }^{\circ} \mathrm{C}$. However, new phases were also detected as summarized in Table and also shown in Fig. 1b, $1 \mathrm{c}$ and $1 \mathrm{~d}$ in addition to the specified phases. Same phases were also detected by F. Oktar et al. [13].

Phases occured during sintering process

TABLE into CSHA- $\mathrm{La}_{2} \mathrm{O}_{3}$ composites.

\begin{tabular}{c|c|c|c}
\hline \hline $\mathrm{T}\left[{ }^{\circ} \mathrm{C}\right]$ & CSHA-2.5 $\mathrm{La}_{2} \mathrm{O}_{3}$ & CSHA-5 $\mathrm{La}_{2} \mathrm{O}_{3}$ & CSHA-10La $\mathrm{O}_{3}$ \\
\hline 900 & \multicolumn{3}{|c}{$\mathrm{HA}, \mathrm{La}(\mathrm{OH})_{3}$ and $\mathrm{La}_{2} \mathrm{O}_{3}$} \\
\hline 1100 & $\mathrm{HA}, \mathrm{La}_{2} \mathrm{O}_{3}$ & $\mathrm{HA}, \mathrm{La}_{2} \mathrm{O}_{3}$, & $\mathrm{HA}, \mathrm{La}(\mathrm{OH})_{3}$ \\
& $\left(\mathrm{H}_{8} \mathrm{La}_{1} \mathrm{O}_{7} \mathrm{P}_{3}\right)$ & $\begin{array}{c}\mathrm{H}_{2} \mathrm{Ca}_{3} \mathrm{O}_{9} \mathrm{P}_{2} \\
\text { and }\left(\mathrm{Ca}(\mathrm{OH})_{2}\right.\end{array}$ & $\mathrm{Ca}_{9}\left(\mathrm{PO}_{4}\right)_{6}\left(\mathrm{PO} \mathrm{PH}_{3} \mathrm{OH}\right)$ \\
& & $\mathrm{HA}, \mathrm{La}_{2} \mathrm{O}_{3}$, & $\mathrm{CaO}, \mathrm{La}_{2} \mathrm{O}_{3}$ and \\
& $\mathrm{HA}, \mathrm{La}_{2} \mathrm{O}_{3}$, & $\mathrm{Ca}(\mathrm{OH})_{2}$ and $\mathrm{CaO}$ & $\mathrm{Ca}_{9}\left(\mathrm{PO}_{4}\right)_{6}\left(\mathrm{PO}_{3} \mathrm{OH}\right)$
\end{tabular}

As shown in Fig. 2 that necks started to form and grow between particles at $900{ }^{\circ} \mathrm{C}$ (Fig. 2a1, 2a2 and 2a3), tubular pores appeared along the grain boundaries at $1100{ }^{\circ} \mathrm{C}$ (Fig. 2b1, 2b2 and 2b3) and the tubular pores break up into isolated quasi-spherical pores typically located at the triple points of grains at $1300{ }^{\circ} \mathrm{C}$ (Fig. 2c1, 2c2 and 2c3). However, grain size decrease by increasing $\mathrm{La}_{2} \mathrm{O}_{3}$ rates so porous microstructures occured for CSHA- $10 \mathrm{La}_{2} \mathrm{O}_{3}$ composites compared to other $\mathrm{La}_{2} \mathrm{O}_{3}$ reinforced samples.

As shown in Fig. 3, the density of all sintered samples increase by ascending sintering temperatures. While the lowest density value was obtained for CSHA-10La ${ }_{2} \mathrm{O}_{3}$ samples $\left(1.82 \pm 0.04 \mathrm{~g} / \mathrm{cm}^{3}\right)$ sintered at $900{ }^{\circ} \mathrm{C}$, the highest density value was obtained for CSHA-2.5 $\mathrm{La}_{2} \mathrm{O}_{3}$ samples $\left(3.06 \pm 0.03 \mathrm{~g} / \mathrm{cm}^{3}\right)$ sintered at $1300{ }^{\circ} \mathrm{C}$. It is also seen that density values of CSHA-2.5 $\mathrm{La}_{2} \mathrm{O}_{3}$ composites are higher than other CSHA- $\mathrm{La}_{2} \mathrm{O}_{3}$ composites. For all sintering temperatures density of CSHA- $\mathrm{La}_{2} \mathrm{O}_{3}$ composites decrease by increasing $\mathrm{La}_{2} \mathrm{O}_{3}$ rates which may related to at higher $\mathrm{La}_{2} \mathrm{O}_{3}$ values diffusion rates. This situation causes the formation of higher porosity. This may be related to particle size of starting powders, milling time, speed and also ball diameters and numbers used during ball milling process.
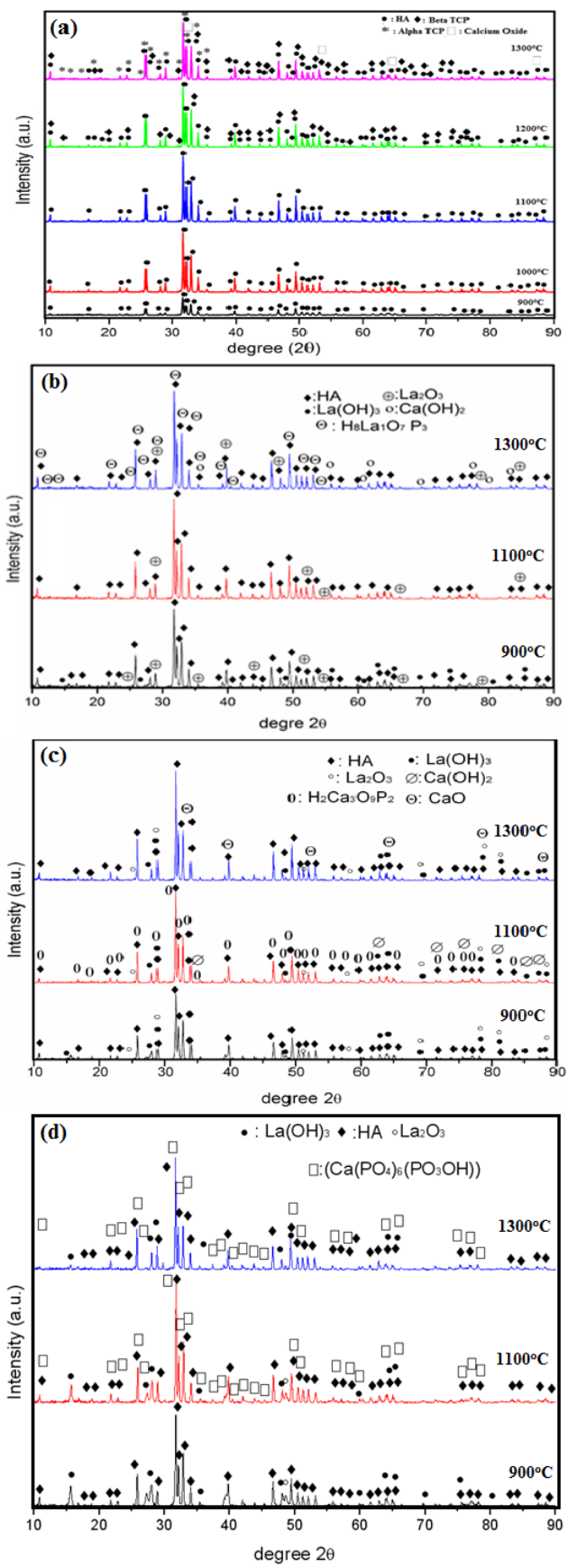

Fig. 1. XRD patterns of (a) pure CSHA, (b) CSHA$2.5 \mathrm{La}_{2} \mathrm{O}_{3}$ (c) CSHA- $5 \mathrm{La}_{2} \mathrm{O}_{3}$ and CSHA- $10 \mathrm{La}_{2} \mathrm{O}_{3}$ composites.

As shown in Fig. 4, the compressive strength of all samples increase by increasing sintering temperatures until $1100{ }^{\circ} \mathrm{C}$ and then decrease at higher sintering temperatures. While the highest compressive strength was obtained to CSHA-5La $\mathrm{L}_{3}$ composites sintered (151 \pm $5.56 \mathrm{MPa}$ ), the lowest density value was obtained to pure CSHA sintered at $1300{ }^{\circ} \mathrm{C}(65 \pm 5.59 \mathrm{MPa})$. Compressive strength of pure CSHA decrease at 1200 and $1300{ }^{\circ} \mathrm{C}$ because of the formation of TCP, whitlockite and $\mathrm{CaO}$ phases, respectively. These formations were also detected to CSHA- $\mathrm{La}_{2} \mathrm{O}_{3}$ composites, but they have 


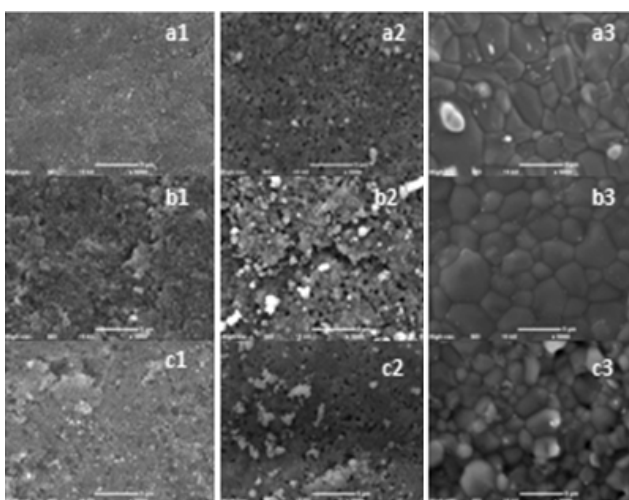

Fig. 2. SEM migrographs of CSHA-2, $5 \mathrm{La}_{2} \mathrm{O}_{3}$ composites sintered at $900{ }^{\circ} \mathrm{C}$ (a1), sintered at $1100{ }^{\circ} \mathrm{C}$ (a2), sintered at $1300{ }^{\circ} \mathrm{C}(\mathrm{a} 3), \mathrm{CSHA}-5 \mathrm{La}_{2} \mathrm{O}_{3}$ composites sintered at $900{ }^{\circ} \mathrm{C}(\mathrm{b} 1)$, sintered at $1100{ }^{\circ} \mathrm{C}(\mathrm{b} 2)$, sintered at $1300{ }^{\circ} \mathrm{C}(\mathrm{b} 3)$ and $\mathrm{CSHA}-10 \mathrm{La}_{2} \mathrm{O}_{3}$ composites sintered at $900{ }^{\circ} \mathrm{C}(\mathrm{c} 1)$, sintered at $1100{ }^{\circ} \mathrm{C}(\mathrm{c} 2)$, sintered at $1300{ }^{\circ} \mathrm{C}(\mathrm{c} 3)$.

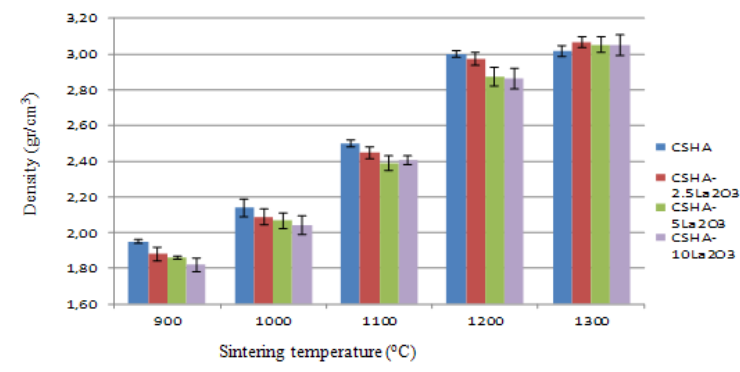

Fig. 3. The effect of sintering temperatures on the density values of the sintered samples.

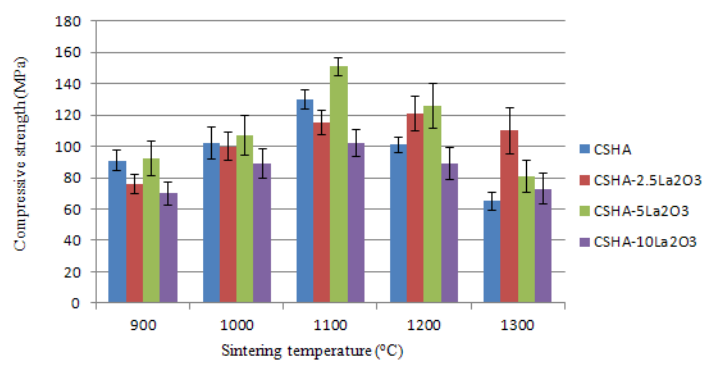

Fig. 4. Compressive strength of the sintered samples as a function of sintering temperature.

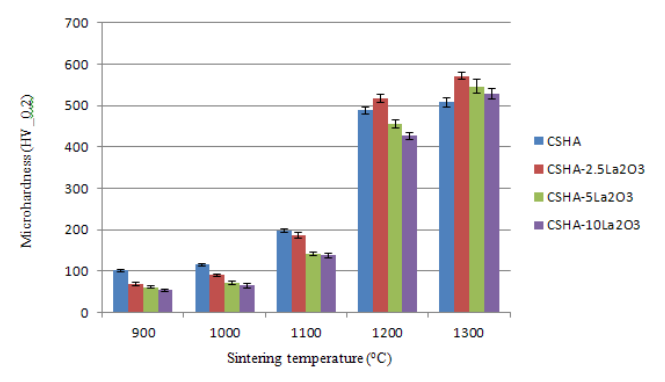

Fig. 5. Microhardness values of the sintered samples as a function of sintering temperature. generally higher strengths compared to pure CSHA which may explain by the decreasing of second or third undesirable phase's rates via $\mathrm{La}_{2} \mathrm{O}_{3}$ reinforcement and due to its reducing effect on the grain growth of HA. Hardness of the sintered ceramics are affected by average grain size, porosity rates and second and/or third phases. As shown in Fig. 5, the hardness values of the samples increase by ascending sintering temperatures. For all sintering temperatures, the highest microhardness values were measured for CSHA-2.5 $\mathrm{La}_{2} \mathrm{O}_{3}$ samples which may explain by lower porosity values, higher grain sizes and lower glassy phases.

\section{Conclusion}

The following conclusions can be drawn from the present study:

The mechanical properties of CSHA can be improved by the reinforcement of $\mathrm{La}_{2} \mathrm{O}_{3}$.

The optimum $\mathrm{La}_{2} \mathrm{O}_{3}$ rate was found $5 \%$ for CSHA$\mathrm{La}_{2} \mathrm{O}_{3}$ composites to obtain higher compressive strength.

The best compressive strengths for all samples were obtained at $1100{ }^{\circ} \mathrm{C}$, however, at higher temperatures compressive strengths of the samples decreased due to occured undesirable second and/or third phases such as $\mathrm{CaO}, \mathrm{TCP}$ and whitlockite.

\section{Acknowledgments}

This work was supported by the Scientific Research Project Program of Marmara University Project No: FEN-C-YLP-130313-0087.

\section{References}

[1] F.N. Oktar, Ceramic. Int. 33, 1309 (2007).

[2] C.Y. Ooi, M. Hamdi, S. Ramesh, Ceramics International 33, 1171 (2007).

[3] N. Demirkol, O. Meydanoglu, H. Gokce, F.N. Oktar, E.S. Kayali, Key Eng. Mat. 493, 588 (2012).

[4] A.J. Ruys, M. Wei, C.C. Sorrell, M.R. Dickson, A. Brandwood, B.K. Milthome, Biomaterials 16, 409 (1995).

[5] M.K. Herliansyah, M. Hamdi, A.I. Ektessabi, M.W. Wildan, J.A. Toque, Mat. Sci. Eng. C 29, 1674 (2009).

[6] G. Göller, F.N. Oktar, Mat. Lett. 56, 142 (2002).

[7] C. Kailasanathana, N. Selvakumar, Ceramic. Int. 38, 3569 (2012).

[8] Huaxia Ji, P.M. Marquis, Biomaterials 13, 744 (1992).

[9] C.Y. Tana, A. Yaghoubia, S. Ramesha, S. Adzilaa, J. Purbolaksonoa, M.A. Hassana, M.G. Kutty, Ceramics Int. 39, 8979 (2013).

[10] F.N. Oktar, S. Agathopoulos, G. Goller, H. Gökçe, E.S. Kayali, S. Salman, Key Eng. Mat. 330, 411 (2007).

[11] Y. Zhang, L. Chen, J. Zeng, K. Zhoa, D. Zhang, Mat. Sci. Eng. C 39, 143 (2014).

[12] British Standard Non-metallic Materials for Surgical Implants. Part 2. Specification for ceramic materials based on alumina, BS 7253: Part 2: 1990.

[13] F.N. Oktar, S. Ozyegin, O. Meydanoglu, H. Aydin, S. Agathopoulos, G. Rocha, B. Sennaroglu, S. Kayali, Key Eng. Mat. 309, 101 (2006). 